the Government has intervened to form State-aided companies, and British Dyes, Ltd., has its French analogue in the "Société Nationale des Matières Colorantes et Produits Chimiques." Meanwhile, private enterprise has played a very important part. The last surviving independent French dye factory at Saint-Denis has greatly increased its capital and organised its resources in order to deal intensively with dye production as soon as the claims of the explosives departments have abated. In Lancashire, Messrs. Levinstein, who have achieved noteworthy success as dye-makers, now form the nucleus of a group of co-ordinated firms working amicably in the production of dyes and other synthetic products. These firms, which include the Ellesmere Port indigo factory and Messrs. Claus, of Clayton, near Manchester, have working arrangements with other industrial undertakings not only in Great Britain, but also so far afield as Italy and America. This combination of the Lancashire colour firms and their associates is at present a most hopeful sign of renaissance for the chemical industries of the Entente Powers.

G. T. Morgan.

\section{FRANCE AND NATIONAL SCIENTIFIC RESEARCH APPLIED TO INDUSTRY.} \section{THE lirench Société d'Encouragement pour} 1 1'Industrie Nationale, always to the fore in matters of vital moment to industry, has recently been dealing with the question of scientific investigation as applied to manufacture. The "Economic Arts" Sub-Committee in particular is greatly interested in the co-ordination and cooperation of the various research and test laboratories in the country with the view of bringing science and industry into more direct contact after the war. In No. I (I9I7) of the society's Bulletin General Sebert has an article on the various establishments of the kind. Many of the Government departments in France have their own special laboratories, e.g. the various research laboratories of the French War Office and the Munitions Inventions Committee. A number of the scientific societies also have their own establishments, e.g. that founded by the Society of Electrical Engineers in I886. Many tests are made there for different Government departments, and a number of important researches in electricity have been undertaken. Then there is the laboratory created by the French Photographic Society, which has done good work for the photographic profession and trade, and, more recently, for the kinematograph trade. By a decree passed in 1900 it was decided to widen the scope of the mechanical laboratory founded in $18_{54}$ by General Morin, the result being the foundation of the Laboratoire d'essais at the Conservatoire national des arts et métiers. To this institution many technical societies have made grants. It is divided into five sections, viz. physics, metals, materials of construction, mechanics, and chemistry. Here certain primary and secondary standards are kept. This laboratory has done good work in the carrying out of routine testing of all kinds, but its operations are evidently circumscribed through lack of funds. The laboratory had to close at the beginning of the war, though it has since been reopened at the instance of the Munitions Inventions Committee for the carrying out of experiments relating to war problems.

Useful as such establishments are, however, there is a strongly felt desire to establish in France a National Laboratory on the scale of our own National Physical Laboratory, the Bureau of Standards (U.S.A.), and the Reichsanstalt at Charlottenburg.

M. Armand Gautier, of the Institute, recently expressed at the Academy of Sciences his personal ideas regarding the creation of a central laboratory of the kind, and an epitome of his contribution is printed in the Bulletin of the Société d'Encouragement already referred to. He suggests the formation of a council consisting of manufacturers of the first rank, scholars who are specialists in particular branches of science, and a small number of Ministers of State or members of the National Council. This council would draw up a list of the questions to be dealt with and appoint the most eminent men to carry out the investigations. The council would also approach the manufacturers, etc., who would be most likely to benefit from the researches, and the latter would do the rest by the provision of annual grants for the execution of the work. The State would have no responsibility, direction, or supervisory powers, but would provide the funds necessary for the establishment and equipment of the institution. Each manufacturer would undertake to assist according to the extent of his business, but the share of each would be fixed as low as possible. M. Gautier thinks that there would be no difficulty in inducing manufacturers to lend their support, as it is they who would most directly profit from the results of the researches.

E. S. Hodgson.

\section{NOTES.}

A Correspondent in Petrograd gives us a rather gloomy account of the difficulties of carrying on scientific work or publications under the present conditions in Russia. He says:- "It is, in fact, now almost impossible to print here scientific works having small circulations, as the prices demanded by the compositors, printers, papermakers, and other workers connected with the production of books are 200-300 per cent. higher than they were in February, immediately before the Revolution. The results are beginning to be felt already-factories are being closed and the number of unemployed getting larger evcry day. Scientific work and teacining are at present almost impossible, as many of the institutes and universities are 'requisitioned' by irresponsible revolutionary organisations and troops; thus the Polytechnic Institute has been occupied since March 5 by about 2500 soldiers, and as the sanitary arrangements were never intended for such a number of people, having no ideas of sanitation, living and sleeping in the lecture- and drawing-halls, the shameful state of the institute may be imagined. All efforts to eject these unwelcome guests ard those of other organisations have proved abortive, as the 'Provisional Government' 